\title{
WHERE DO SONGS COME FROM? AN ATTEMPT TO EXPLAIN SOME VERSES OF REGILAUL
}

\author{
Aado Lintrop
}

\begin{abstract}
The Estonian earlier folk song, regilaul, about the singer indicates that the singer had a special position in the community, but the singing skill had rather just become attached to them, and was not acquired voluntarily (similarly to the knowledge of the Tibetan singers that usually comes about on its own, irrespective of the will of the humans). The songs indicate that one learnt to sing when attending weddings, working or being in contact with nature. Occasionally the talent for singing was acquired magically. Interesting are regilaul texts in which the singer says that she cannot sing because of lack of some objects, e.g. laululeht, sõnasõlg (a sheet of song, a brooch of words), etc. In some cultures singers of long epic texts believed in the help of supernatural beings and also used some helping devices like a bronze mirror, a sheet of paper, etc. for better concentration. In the article I try to point out that some formulas of Estonian regilaul like a sheet of song, a brooch of words, and the quill of the mouth may be distant memories of the singers who needed actual helping devices, believing in which aided them in a better recreation of their texts.
\end{abstract}

Keywords: oral tradition, regilaul, shamanism, singers of epic, text reconstruction

\section{FOLKLORE AS AN ENDLESS PROCESS}

My starting point for the topic is that folklore is in a constant change in time. This would not have to be repeated if, even up to this day, folklore scholarship and the related spheres did not operate with judgemental notions, such as 'original', 'primal', 'authentic', 'genuine', etc. If we presume a constant change in folklore, we have to accept that the roots of the 'original' or 'primal' go back to the time when humans first became separated from the animal kingdom. One phenomenon would provide fertile ground for another and this continued for thousands of times. Thus we shall never learn what the ultimate beginning was like. Secondly, when speaking about cultural phenomena, we should bear in mind that their content usually changes more rapidly than their structure. Both of the aspects have been repeated recently by a Danish historian of religion, Jens 
Peter Schjødt (2014: 44-47). Our everyday language provides us with telling examples of a changed content (or meaning) as we still use phrases such as meelt lahutama (to entertain, literally 'dissolve the mind'), hinge (tagasi) tõmbama (to take a break, lit. 'draw (back) the soul'), leiba luusse laskma (to rest after a meal, 'let the bread into the bones'), and say that päiv läts jumalihe ('the Sun went to the Creator' in south-Estonian dialect). Some of us even 'have birddeception' in the morning when they have an early breakfast before going out. ${ }^{1}$

\section{SOME MOTIFS OF REGILAUL ARE OLDER THAN SONGS THEMSELVES}

I have observed regilaul from similar vantage points also earlier, and I thus presume that it is constantly changing while alive and that its constituent parts last longer than the whole. I also think that some of them are older than regilaul itself. I have not attempted to find the starting point for regilaul, for I believe that it did not exist during a clear-cut period anyway. Still, I do believe that spells and dirges allow us to glance into the world preceding the regilaul, as do the runo songs from Finland and Karelia, for we can find many building blocks of the Estonian regilaul in them. Departing from my own interests, I have been looking for such components of regilaul that at a time in the past (I emphasise that this does not mean 'originally') could have been related to some activities or understandings belonging to the realm of religion. As a researcher of north-Eurasian shamanism and religions of eastern Finno-Ugric peoples I have collected a plethora of different examples of creating and performing long epic songs, and therefore I often tend to compare such regilaul parts with traditions of other peoples. Looking for shamanic parallels is not a new attempt for me. In 2006 my paper about distant reflections of Mongolian Monkh Khokh Tenger ('eternal blue sky') in regilaul was published (Lintrop 2006). Some years ago I also studied aspects of ritual storytelling and riddling (Lintrop 2012) to point at the connections between religion and performing, especially in the belief of special spirit helpers of storytelling or singing and in the credence of entertaining supernatural visitors of critical times with stories and riddles. 


\section{PERFORMERS OF GESAR EPIC}

The tradition of the Epic of King Gesar that was included in the UNESCO Intangible Cultural Heritage List in the same year (2009) as the Seto song tradition leelo originating in the southeast of Estonia is remarkable because the performing of the epic is tightly united with religious rites and meditation. In today's Tibet there are approximately a hundred singers who can perform texts consisting of tens of thousands of lines by heart. Some of them (bab sgrung) claim that the epic was revealed to them in long dreams (they wear a special head covering when singing); others (dag snang sgrung) learn parts of the epic during short revelations that resemble flashes of light; a third category (dgongs gten) excavate the epic from within themselves; the fourth group (gter don) find it somewhere in the vicinity like a hidden treasure; the fifth set (pra phab) claims that they can see the text in a bronze mirror while singing and cannot perform the epic without the mirror (Zhambei 2001: 280-285). The latter is an extremely widespread helping device of the shaman in Tibet, Mongolia, Buryatia, Tyva, Altay, etc. The pra phab technique derives from the Bön religion (ibid.: 284) where it was used to make predictions. Although as of 1977 the Bön has had the same rights as the Buddhist schools, its roots are deep in the shamanistic soil. The singers who are considered the best, those who have had revelations in their dreams, have been able to remember unbelievably long texts. Thus 600,000 lines of the epic have been recorded from a Tibetan singer, Thrapa, while another old singer, Samthrub, has provided 700,000 verses (ibid.: 281). All of the bab sgrung saw meaningful dreams at 9-16 years of age. Some were shown extensive scenes from the epic in which they themselves participated, others would meet gods who told them to start singing, and some read thousands of manually recorded pages of the epic in their dreams (Yang 1998: 432).

In the context of this article it is important to accentuate once again that Tibetan Buddhism and shamanism are closely related. In his classical study about Tamang ${ }^{2}$ shamans, Larry Peters writes:

The two major types of Tamang religious specialists are lama (priests) and bombo (shamans). [---] Lama and bombo fulfill different social functions in the community. As mentioned earlier, the lama's primary responsibility is officiation at funeral ceremonies. The bombo's main duty is to perform healing rituals. (Peters 2007 [1998]: 55)

Next he presents a Tamang legend of how Guru Rinpoche himself made this distinction. Tibetan shamans (lhapas) also refer to Padmasambhava (Tibetan pad ma 'byung gnas) (see Sarah C. Cifers' documentary "Fate of the Lhapa", 
2007). Researcher of Changpa ${ }^{3}$ nomads' shamanism, Ina Rösing, writes about the situation in Ladakh (Jammu and Kashmir, India):

The Buddhist clergy does not believe there is any contradiction between shamanic practice and Buddhist faith, but quite clearly assigns to shamanism its rightful place [---]. What is also quite plain to see is that the one Buddhist dignitary of Ladakh, who today plays the most important role as a key figure in shamanic calling - Stakna Rinpoche - does see shamanism very favourably. (Rösing 2006: 155) ${ }^{4}$

In the area of Tibetan Buddhism we can found lamas and shamans acting side by side everywhere. It enables me to compare performances of the Tibetan Gesar epic with Khakas epic songs and even with the songs of Siberian shamans and Ob-Ugrian bear feast.

\section{SINGERS OF KHAKAS EPIC SONGS}

The singers of the Khakas epic stories khai (khaiji), who believed that they had received their gift from specific spirits khai eezi, were convinced that after the spirit had entered them and the spirits of the characters in the story had been evoked during the storytelling, the performance must not be broken off, but the characters were to be sent to rest by telling the tale to the end. If a pause was desired during the long performance, a moment when the characters were partying had to be chosen for this purpose. If the story was left unfinished so that the heroes did not overcome the evil beings featured in it, the latter would start to cause harm to people. The heroes of the tale, when left to their own devices, could even kill the singer in revenge. The khaiji of the Khakas were (and still are) shaman-like characters who went through an initiation during which they got in touch with spirits with the help of the mountain spirits tag eezi. They have described performing a song as follows: "I close my eyes and see scenes unrolling, which I then describe" (Van Deusen 2004: 78).

\section{SHAMAN SONGS AND KHANTY BEAR FEAST SINGERS}

Next we can mention a shaman song in the form in which it has been preserved in several places in northern Eurasia. This is closely related to the idea that it is not their own text that the shamans perform during rituals, but their spirit helpers' text that they can see or live through simultaneously. In such cases, the shamans themselves identify with the main active being in the text. 
The singers at a Khanty bear feast wear special headgear and smocks while presenting songs about the life of the bear. The long songs that can last for a couple of hours are delivered with the singers' eyes closed as if they would thus better see the events being sung about. The songs are special; they must not be broken off in the middle as they describe the emergence of the world order, the functions and living places of deities, and the gifts that the supernatural beings attending the feast are bringing to humans. An important place belongs to the song staff or song tree on which the host of the feast makes a knife mark for each performed song.

These are but a few examples of the specifics of performing epics in the wide world.

\section{SOME REMARKS ABOUT THE REGILAUL TRADITION}

The Estonian regilaul about the singer indicates that the singer had a special position in the community, but the singing skill had rather just become attached to them, and was not acquired voluntarily (similarly to the knowledge or shamanic gift of the Tibetan singers that usually comes about on its own, irrespective of the will of the humans). According to the songs, one learnt to sing when attending weddings, working or being in contact with nature. Occasionally the talent for singing was acquired magically, for instance, when drinking out of the singer's piggin or eating a crane's throat. Heritage as a phenomenon to be consciously acquired, maintained, and transmitted did not exist at the time when regilaul was recorded. People would just live and do their things as they had always been living and doing, and songs were a part of the mode of living that had been continuing for generations. Even the concept of regilaul was not used before the newer folk songs started to spread. It may have been simply a 'song', or 'our song' and 'singing in our way' versus a strange or different song, and singing in a different (Latvian, Russian, etc. way). Ingrid Rüütel has written on this topic:

The old Baltic-Finnic word laulu, laulemahan was originally used first and foremost about the runo song, and was later transferred to other, newer phenomena (newer folk songs, hymns, school songs, and choir songs). The word occurs with all Baltic-Finnic peoples who had runo songs (resp. regilaul) as well as Livonians. Special signifiers for the old folk song are different in case of different peoples as well as different regions of the same country; they are usually of foreign origin and apparently have emerged later in order to differentiate between old folk songs and any newer songs. (Rüütel 1999: 91) 
The missing of the heritage concept did not mean that the ancestors' wisdom was not cherished or passed down from generation to generation. What were involved here were pieces of wisdom that were expected to be of help when trying to manage in different situations. And folklore itself contained several control mechanisms that had to guarantee its continuation. Thus there were tales that contained warning examples of what would happen when old customs were not observed, and there may have been talk about what might come about when spells, dirges, and songs were used improperly or left unused. Only a few examples of this kind, mostly concerned with forwarding words of magic, the harm of excessive lamenting, and singing and merry-making at a forbidden time, have been passed down to us. However, considering the example of other peoples, we might presume the existence of the kind of texts, the task of which was to emphasize the dire necessity of singing at particular moments and in certain situations.

\section{ABOUT THE ESTONIAN EPIC SONGS}

The heritage that has survived until this day shows that songs were closely related to people's daily life (the layer of working songs and songs of tradition). At the same time, some lengthy narrative songs and elements shared with Karelian and Finnish epic songs indicate that songs were sung not only in the field, when making hay, or when engaged in handicraft at home, during weddings and funerals, in inns and at village dances, but also on other occasions. It can be assumed that during Estonians' night-long singing and dancing before the battle on Öland Island in 1170, described in Gesta Danorum (book XIV), mostly war songs (heroic epics) were sung. These have not reached us at all (although one of the older epic songs, "The Brother's War Tale", might include single elements from these). The heroic epics, or rather, their scarcity in the nineteenth and twentieth centuries, when the majority of Estonian folklore collections were formed, serve as a good example of how songs that lose their function when circumstances change fade away. At the same time, the abundance of songs of tradition points at the significance of customs in heritage maintenance.

Maybe long epic songs were specially performed to be listened to during long winter evenings? During the very time that later would become connected with riddle-making and storytelling? Maybe this was related to the idea that singing entertains supernatural beings, the way that many cultures have felt about storytelling (see Lintrop 2012: 396-412). There may have even been beliefs that singing not only entertains different gods and spirits, but also shows them that people are familiar with the order and rules that they have 
imposed, the way expressed in the songs of the Ob-Ugrians' bear feasts (see Lintrop 2014: 147). There are some things that we shall never know for certain, which will always remain dependent on the theory in the light of which they are viewed. Yet I believe that we may still presume one thing: once, the proportion of narrative songs was higher than at the time when regilaul was 'hewn into books'. Although I have used the formula from the parallel verses kõik ma panin paberisse / raiusin ma raamatusse (I put everything into paper / I hewed everything into a book) as a figure for collecting (recording) regilaul, these verses certainly do not indicate the literacy of the performer or the author of the song, but rather show the attitude of the illiterate singer towards the recorded text as a magical object.

\section{PERFORMING OF THE LONG EPIC SONGS: SOME PERFORMANCE TOOLS IN TIBET}

Long songs (that often contain mythology) demand a good memory and an ability to recall/create the text on the part of the singer, which an onlooker may find to be so special that it is considered to be supernatural. The impression may be strengthened by the conviction that, in addition to people, the performance can also be heard by gods or the characters with whom the singing is concerned. Even more natural is the presumption of supernatural help in case the singer is believed to deliver the words of gods or supernatural heroes. Today we can speak of altered states of consciousness (or trance-like states) that the singers reach by shutting their eyes, controlled breathing, and the singing itself, as states that can help access the information stored in memory. However, the old interpretation thereof was probably a supernatural one. In addition, also other devices may have been employed: fixing one's glance on fire or on gleaming objects or both combined, for example, light reflecting from silver. Such devices have been used in several places to reach a trance-like state. Again, I resort to some examples concerning Tibetan singers.

Even a piece of paper can become a performance tool. Young artist Grags pa seng ge says that when he holds a piece of paper in his hand and looks into it, the epic appears in his head and smooths [sic] his performance. Since Grags pa seng ge is illiterate, the paper provides him no aidememoire; indeed, a blank sheet or a newspaper will serve the purpose. (Yang 1998: 430) 
The same singer is introduced as an example by John Miles Foley in his book titled How to Read an Oral Poem (a picture of the singer adorns the cover of the book). Foley adds: "In other words, what is the text for us is for him a talisman, a symbolic piece of his singing equipment" (Foley 2002: 3). Still, sheets of paper are not the only symbolic helping devices in Tibet. Many performers of the Gesar epics would wear a special headgear without which the performance was impossible. The use of the bronze mirror is described in the following excerpt:

Another Tibetan artist, Kha tsha pra pa nyag dbang rgya mtsho, uses many tools before beginning a song. First, he must set up a sacred altar, stand a bronze mirror in a bronze plate containing barley, place a crystal in front of the mirror, light incense on the side, place a butter lamp in front of the plate and two tall bronze glasses on each side of the plate. (Yang 1998: 430)

\section{POSSIBLE PERFORMANCE TOOLS NAMED IN REGILAUL}

Could the parallel pair of words in our regilaul, 'the sheet of song / the brooch of words' and 'the clink of the tongue / the quill of the mouth' be a distant reflection of something similar - distant memories of the singers needing actual helping devices, believing in which aided them in a better recreation of their text?

Siis ma vele Riiga virota

Tõsõ saada Saarõmaale

Säält lasõ tuvva laulu lehe

Laulu lehe sõna sõle.

(EÜS IX 1501/2 (91) < Räpina 1912)

Then I'll cast my brother to Riga,

Send the other to Saaremaa,

Let them fetch a sheet of song,

A sheet of song, a brooch of words.

In addition, singers can also complain of an inability to sing as long as they have no quill of the mouth:

Mul jäi koju suuda sulge,

Laua peale laulu lehte,

Kirstu nurka keele kõlks.

(EÜS I 1047 (46) < Vändra 1904) 
I left the quill of the mouth at home,

The sheet of song upon the table,

The clink of the tongue in the chest corner.

It can come to one's mind that the quill of the mouth in this song may show the attempts made to let oral heritage seem more elevated with the help of literacy skills. By the way, as an aside it can be said that several Tibetan singers who claimed to have learnt their text from a manuscript they had found, actually first wrote down their stories, then hid them, and dug them out in the presence of witnesses (Zhambei 2001: 285).

Still, there are no unambiguous explanations when it comes to regilaul. Let us observe song versions of the types "On Mother's Grave", "Proud Maiden", and "Husband-Killer":

Ann oli Harju neitsikene,

Tantsis Tarvasti mäele;

Sulg oli suus, pärg oli pääs,

Hõbe õuna tal peosse.

Läks tema kurni kukutama.

(EÜS IV 1652/3 (132) < Pilistvere 1907)

Ann was a maiden from Harju,

Went dancing up the hill of Tarvasti,

A quill in her mouth, a wreath on her head,

A silver apple in her hand.

She went to let the pins fall.

Mari oli muru madala

Angerpikk ja peenike'

Kõndis ta seal Tõnnismäel,

Sulg oli suus ja pärg oli peas,

(EÜS V 1146 (194) < Risti 1908)

Mari was lowly like the grass,

Long like an eel and slim,

She was walking on Tõnnismägi hill,

A quill in her mouth and a wreath on her head. 
Mai oli maias neitsikene,

Sulg oli suus ja pärg oli pääs,

Haava leht oli hambaassa,

Jürgi soiti tieda müöda,

Hakas Maije kutsumaie.

(H II 34, 215/7 (94) < Kuusalu 1892)

Mai the maid had a sweet tooth,

A quill in her mouth and a wreath on her head,

An aspen leaf between her teeth,

Jürgi was driving on the road,

Started to call Mai.

The fixed formula in all these is the verse sulg oli suus ja pärg oli pääs ('a quill in her mouth and a wreath on her head'), which as if expresses the pride or nobility of the maiden. The wreath does that, but why the quill? It is certainly not referring to the literal culture nor was the quill a part of Estonian maiden's national costume. With many peoples we can find a simple wind instrument made of a bird's feather (usually that of a goose). It could be suspected that the above examples may refer to this. A proud maiden is dancing and blowing an instrument as an accompanying rhythm. Couldn't this have been an old method of bringing about a state of trance as a background? Several versions of the song deal with death and the other side. In 1989 an instrument made of a goose feather was demonstrated by Dulsimyaku, the son of a Nganasan shaman I knew. I asked Igor Tõnurist, an Estonian scholar of folk music, if there were reports from Estonia on instruments made of feathers, and this is the answer I received:

All descriptions indicate that it was certainly an instrument like the clarinet, i.e. at the one end of the length of the goose feather tube an oblong reed is cut, just like in an ordinary reed instrument or an instrument made of a rye stalk. It seems to have been a simple device for creating sounds, which was apparently used as a children's toy, or else was put in the upper part of the chanter of a bagpipe as a reed making sounds like an ordinary cane reed. (Tõnurist 2013)

What is notable, though, is that some texts still speak of a brooch instead of a quill. True, these versions are few:

Ann oli hakki neitsikene, Tantsis Tarvastu mäella, 
Minu valge venna kõrvas,

Punapea poisi kõrvas,

Sõlg oli rinnas, pärg oli peas,

Korda põlle varviessa,

Kolm oli küinalta käessa.

Ühes oli tuli punane,

Teises oli tuli sinine,

Kolmandas tuli kollane.

(E, A 175/8 (3) < Põltsamaa 1893)

Ann was an eager maiden.

Danced on Tarvastu hill.

Side by side with my white brother,

Side by side with the read-headed boy,

A brooch on her breast, a wreath on her head,

Crinkles in her apron.

She had three candles in her hand,

One had a red light,

The other had a blue light,

The third one had a yellow light.

The above excerpt is unusual with its three coloured candles, directing the thoughts towards the red goose in the rainbow or a cloud on whose tail there is a bed and in it three or four maidens (or some other mythological characters) who determine human fates:

Vikerkaaris purjed suured,

Purjes on hani punane,

Hane saba on sinine.

Saba peal on saksa sängi,

Mis seal sängide seessa?

Neli noorta neitsikesta ...

(H II 10, 34/6 (25) < Kadrina 1889)

In the rainbow the big sails,

In the sail a red goose,

The goose's tail is blue.

On the goose's tail is a fine bed,

What is inside the bed?

Four young maidens... 
It could be guessed that the quill of the mouth is in a way more 'original', and the brooch a more recent interpretation, which arose due to alliteration, but the brooch emerges as important in connection with singing also elsewhere. I have observed that the motif of making the brooch row may have been related to foretelling the future (Lintrop 2008: 248-249), but it may have been connected with songs accompanying other magic-related activities as well:

Võtsin sõle rinnasta,

lehe laia kaelasta,

panin sõle sõudema,

lehe laia lendama:

"Sõua, sõlge, lenda, lehte!"

(Haljala (ER 1926: 203))

I took the brooch from my breast,

The broad sheet from my neck,

I made the brooch row,

The broad sheet fly:

"Row, my broach, fly, my sheet!"

We shall certainly never learn how the brooch would row. Was it used as a pendulum and moved across some objects? It is possible. Or else, was the light reflecting from the silver that was observed? This is also possible. We only know that the Sami have used a horseshoe brooch as the pointer of the drum (Zachrisson 1991: 89, 93), and that the Udmurt sages have been divining by looking at silver (see, e.g., Bogayevsky 1890: 124-125). The only thing that is certain is that the brooch is an object that has a magical meaning and this is felt even today. For instance, in Setomaa region the motif of taking words from (or below) the brooch has been used even in more recent songs:

Sõlõ päält ma sõna võti, tele päält ma laulu teie.

(Veera Pähnapuu. The song went through Setomaa, created in 1977 (Sarv 1995: 55-58))

I took words from the brooch,

Made the song from the axis [of brooch].

Another place where words are put and from where they are received is the sieve (also an old aiding device when it comes to divination). For instance, a men's song from Setomaa says: 
Sõna-ks sõnaq miq küll võti vaie sõgla-ks sõgla päältä, laulu-ks laulu võti viie vaie lavva-ks lavva päältä.

(Personal song repertoire of Aado Lintrop, learnt from Urmas Kalla in Seto Men's Choir Liinats'uraq.)

Words, well, words I did take from the sieve, Song, well the song I took from the table.

The quill, the brooch, the song sheet, the song table, etc. are probably not particularly new additions in regilaul, but are rather connected with some imaginary concepts that have been forgotten by now. One is tempted to suggest which the most 'original' helping devices for recalling the song texts are, yet I shall not do this. Based on the examples from among other peoples it can be admitted that such helping devices that induced a belief in one's abilities were required and that occasionally these devices were also used in divination.

\section{WHERE DO SONGS COME FROM?}

Finally, I come to the title of the article and pose the question if the snakes, fish, and birds in regilaul from whom singing is learnt ('I took the tale from the mouth of the burbot'; 'The snake sang from the turf / the lizard from within the ground / the rat from the tussock', etc.) could be a remnant of something similar. In this regard, the beings who do not sing in reality are of special interest, for it is not particularly surprising that birds teach someone to sing ('The duck had many words / the lark songs in excess'). But a snake, a lizard, a rat, a burbot or a pike are no singers. At the same time, those mentioned first are popular spirit helpers of the shaman, while the great shaman of the Finns, Väinamöinen, made the first kantele from the jawbone of a pike.

What should certainly not be forgotten in interpreting regilaul is the creative role of alliteration. The variation-filled answer to the question whence the songs have been acquired can always be interpreted as meaning that a talented person can make a song out of anything.

Lu'ud ma võtsin lutsu suusta,

Laulud lattika ninasta,

Kõned kiissa keele pealta,

Aru havi ammastesta.

(H II 27, 532/4 (1) < Palamuse 1889) 
The tales I took from the mouth of the burbot, The songs from the nose of the bream,

The speeches from the tongue of the ruffe,

The meaning from the teeth of the pike.

I still think that similarly to shamanic rituals, singing and storytelling at certain times had the function of guaranteeing the welfare of the community; not only did the songs and the stories create social groups (us vs. these who eat, dress, speak, and sing in a wrong manner and thus are no proper people), but they would also keep them functioning. And in such cases, certainly hints may have been made that the words and the music came to the singer or the storyteller in a supernatural manner.

\section{ACKNOWLEDGEMENTS}

This study was supported by the Estonian Ministry of Education and Research (IUT 22-4, "Folklore in the Process of Cultural Communication: Ideologies and Communities"), and by the European Union through the European Regional Development Fund (Centre of Excellence in Estonian Studies).

\section{NOTES}

1 It is connected with the belief that soul has the shape of a bird. So going outside without giving it some food may cause a situation when birds lure the hungry soul with them.

2 The Tamang are Tibeto-Burmese speaking Buddhist people in Nepal.

${ }^{3}$ Nomadic people in Tibet and Ladakh, living on the Changtang high altitude plateau.

${ }^{4}$ Rösing explains that included in Stakna Rinpoche's duties "is the task of taking care of people who are brought to him because they are 'mad' and who want to know whether the 'madness' might be a symptom of a lha/de struggle, with a calling to become a shaman" (Rösing 2006: 152).

\section{ARCHIVAL SOURCES}

\section{Estonian Folklore Archives at the Estonian Literary Museum}

E - manuscript collection of M. J. Eisen

EÜS - manuscript collection of Estonian Students' Society

$\mathrm{H}$ - manuscript collection of Jakob Hurt 


\section{REFERENCES}

Bogayevsky 1890 = Bogaevskii, Petr. Ocherki religioznykh predstavlenii votiakov. [Outlines of Religious Views of the Votyaks.] Etnograficheskoe obozrenie, Nos. 1, 2, 4.

ER 1926 = Eesti rahvalaulud Dr. Jakob Hurda ja teiste kogudest. Esimene köide. [Estonian Folk Songs from the Collections of Dr Jakob Hurt and Others. Volume 1.] Eesti Kirjanduse Seltsi Toimetused nr. 21. Tartu: Eesti Kirjanduse Selts. Available at http://www.etera.ee/zoom/1149/view?page=13\&p=separate\&view=0,0,2225,3294, last accessed on February 9, 2017.

Foley, John Miles 2002. How to Read an Oral Poem. Urbana and Chicago: University of Illinois Press.

Lintrop, Aado 2006. Distant Reflections of Monkh Khokh Tenger: Some Motifs of Shamanic Journey in Estonian Runo Songs. In: G. Gerelbaatar \& J. Shiilegmaa Monkh tenger sudlal: Munkhtenger Studies. Ulaanbaatar: Mønkh tenger sudlalyn delkhiin akademi, Ikh Mongol uls baiguulagdsany 800 zhiliin oin Yndesnii Khoroo, pp. 196-211.

Lintrop, Aado 2008. Divination in Estonian Regi-Songs. In: Dace Bula \& Sigrid Rieuwerts (eds.) Singing the Nations: Herder's Legacy. Trier: Wissenschaftlicher Verlag Trier, pp. 242-250.

Lintrop, Aado 2012. Great Oxen of Twilight. Storytelling and Riddlemaking at Calendar Solstices. In: Frog \& Anna-Leena Siikala \& Eila Stepanova (eds.) Mythic Discourses: Studies in Uralic Traditions. Studia Fennica Folkloristica 20. Helsinki: Finnish Literature Society, pp. 396-412.

Lintrop, Aado 2014. Loomisaja lood: Uurimusi ja tõlkeid Põhja-Euraasia rahvaste usundist. [Tales of the Time of Creation: Studies and Translations from Religions of Northern-Eurasian Peoples.] Eesti Rahvaluule Arhiivi toimetused 32. Tartu: Eesti Kirjandusmuuseumi Teaduskirjastus.

Peters, Larry 2007 [1998]. Tamang Shamans: An Ethnopsychiatric Study of Ecstasy and Healing in Nepal. New Dehli: Nirala Publications.

Rösing, Ina 2006. Shamanic Trance and Amnesia: With the Shamans of the Changpa Nomads in Ladakhi Changthang. New Delhi: Concept Publishing Company.

Rüütel, Ingrid 1999. Varafolkloorsetelt vokaaližanridelt lauluni III. [From Early Folkloric Vocal Genres to Song III.] Mäetagused, Vol. 10, pp. 90-105. DOI: 10.7592/ MT1999.10.rtl.

Sarv, Vaike (comp.) 1995. Veera Pähnapuu-Setukeste rahvalaule / Setukaisten kansanlauluja / Setu Folk Songs / Setuskie narodnye pesni. Edited by Antti Koiranen. Tampere: Tampereen yliopisto.

Schjødt, Jens Peter 2014. Folkloristic Material and Pre-Christian Scandinavian Religion. In: Eldar Heide \& Karen Bek-Pedersen (eds.) New Focus on Retrospective Methods. Resuming Methodological Discussions: Case Studies from Northern Europe. FFC 307. Helsinki: Academia Scientiarum Fennica, pp. 42-58.

Tõnurist, Igor 2013. Instruments made of feathers. E-mail message to Aado Lintrop. April 17. Van Deusen, Kira 2004. Singing Story, Healing Drum: Shamans and Storytellers of Turkic Siberia. Montreal \& Kingston \& London \& Ithaca: McGill-Queen's University Press; Seattle: University of Washington Press. 
Yang, Enhong 1998. A Comparative Study of the Singing Styles of Mongolian and Tibetan Geser/Gesar Artists. Oral Tradition, Vol. 13, No. 2, pp. 422-434. Available at http://journal.oraltradition.org/files/articles/13ii/8_enhong.pdf, last accessed on February 8, 2017.

Zachrisson, Inger 1991. The Saami Shaman Drums: Some Reflexions from an Archaeological Perspective. In: Tore Ahlbäck \& Jan Bergman (eds.) The Saami Shaman Drum. Based on Papers Read at the Symposium on the Saami Shaman Drum held at Åbo, Finland, on the 19th-20th of August 1988. Åbo: The Donner Institute for Research in Religious and Cultural History, pp. 80-95. Available at https://ojs. abo.fi/ojs/index.php/scripta/article/view/531, last accessed on February 9, 2017.

Zhambei, Gyaltsho 2001. Bab Sgrung: Tibetan Epic Singers. Oral Tradition, Vol. 16, No. 2, pp. 280-293. Available at http://journal.oraltradition.org/files/articles/16ii/ Zhambei.pdf, last accessed on February 9, 2017.

Aado Lintrop ( $\mathrm{PhD}$ in Estonian and comparative folklore) is senior researcher at the Estonian Folklore Archives of the Estonian Literary Museum, Estonia.

aado@folklore.ee 